What does it mean to be an early childhood educator? Negotiating professionalism during practicum placements in Buenos Aires (Argentina)

Jennifer Guevara ${ }^{\mathrm{a}}$

a Institute of Education, Dublin City University, Dublin, Ireland

Drumcondra Rd Upper, Drumcondra, Dublin 9, Ireland (D09DY00). E-mail:

jennifer.guevara@dcu.ie

Doctor of Education (Universidad de San Andrés, Argentina). Rising Talent Fellow (Dublin City University, Ireland). 


\title{
What does it mean to be an early childhood educator? Negotiating professionalism during practicum placements in Buenos Aires (Argentina)
}

\author{
Professionalism is not defined a priori, but rather within a professional community, in \\ the immediate contexts where professionals interact. It is a situated phenomenon that \\ cannot be accounted for without the voices of members of the professional community. \\ In this article, I discuss professionalism through the perspectives of early childhood \\ (EC) teacher educators during practicum placements. Placements are a microcosm that \\ offers a forum for discussing and researching processes in situ within the professional \\ community. The article draws on 11 in-depth interviews and 150 hours of participant \\ observation in a Teacher Education Institute in Buenos Aires (Argentina). Results show \\ EC teacher educators construct and (re)negotiate professionalism through discourses \\ and practices of assertion and resistance banalisation, schoolification and fordification \\ of early childhood education. Results show that professionalism unfolds from \\ collective and individual practical wisdom, a sensitivity and awareness of particular \\ situations that is tacit and embodied in the most experienced.
}

Keywords: early childhood education and care; early childhood educators; early childhood professionalism; early childhood teachers education; practical wisdom.

\section{Introduction}

What does it mean to act professionally as an early childhood (EC) educator? Certainly there is not only one possible answer to this question. Facing complex situations daily seems to be the norm, rather than the exception in the early childhood education (ECE) field. Even the simplest situations educators face every day are puzzling and uncertain (Urban 2008). As Donald Schön lucidly explained in the early 1980s, problems in practice do not present as already defined, outcomes cannot be predetermined, and courses of action cannot be clearly defined as right or wrong. In order to make sense of initially puzzling situations, EC educators draw on a set of knowledge, practices and values that connect the hand, the heart, and the head (Brühlmeier 2010). 
From that perspective, professionalism in ECE is not defined a priori, but rather in situ within a professional community:

...professionalism in early childhood practice cannot be defined in simple universalistic and immutable terms, or through finite lists of qualities and attributes. Rather, (...) [it] is something whose meaning appears to be embedded in local contexts, visible in relational interactions, ethical and political in nature (Dalli, Miller, and Urban 2012, 6).

My aim in this paper is to examine teacher educators' perspectives on what it means (and does not mean) to act professionally in the ECE field. Professionalism has been widely discussed as a 'multidimensional and multilayered phenomenon that is historically, culturally and socially situated' (Lazzari 2012, 261). Professionalism cannot be defined outside the professional community due to the uncertain nature of educational practices (Urban 2010). This means questions around ECE professionalism need to rely on the voices and perspectives of members of that professional community (Peterson et al. 2016; Brock 2013).

In this paper, I understand professionalism from a sociocultural perspective. According to Dalli, Miller, and Urban (2012), professionalism is not a static quality of the person, but rather it emerges in the interaction between members of a professional community. From this perspective, professionalism is continuously shaped as a result of these negotiations, that might take the form of struggles (Kinos 2010). It is constructed and negotiated in the immediate contexts where ECE professionals act and interact, practicum placements being one them.

As Schön (1983) would describe it, the practicum is a setting designed for the task of learning a practice. In the case of teacher education, it takes place through school placements and involves the teacher educator (or tutor), the cooperating teacher, and the student teacher. This makes placements create a unique opportunity to examine processes in situ from a ecological perspective (Zeichner, 1987). Thus, they offer a forum for research and discussion 
around professionalism, since they comprise a set of 'shaped opportunities for the construction and maintenance of professional identities' (Trent 2014, 30).

During placements, teacher educators and cooperating teachers pass on their practical wisdom - a type of knowledge that is present in those who are experienced. Practical wisdom is mostly tacit and embodied in the most experienced as it is a

'sensitivity for and awareness of the essentials of a particular practice situation that shape our perception of a situation, and help us find possible courses of action. (...) it is connected to our sensory organs (...). For this reason, it is hard to make practical wisdom fully explicit' (Lunenberg and Korthagen 2009, 228).

In practicum placements, teacher educators have to make their practical wisdom visible and explicit in order to pass it on to student teachers, which makes them an excellent opportunity for research.

What is more, placements bring together two different domains that are often disconnected: higher education institutions and ECE settings. This unique engagement favours the emergence of differences and the need for resolutions and compromises.

Teacher education, like education in general, is a profoundly political practice. This, too, applies to the placement. However, the literature has focused on its training aspect, not paying enough attention to its political nature (Guevara, 2016). In fact, the term training lies on a technical perspective/paradigm that is unsuitable for understanding the education of autonomous ECE professional.

I understand the placement as a political space where professionalism is (re)negotiated and constructed within the professional community. In this paper, they are analysed from an ecological perspective as arenas of struggle, where professionalism is not necessarily harmoniously negotiated, but rather through practices of assertion and resistance (Fenech, Sumsion, and Shepherd 2010; Ritter 2007). 
In this article, I discuss professionalism through the perspectives of teacher educators as members of the professional community. This approach sheds light on key players in the placements that have been often overlooked by the literature (Dayan 2008; Lawson et al. 2015).

\section{Background of the study: Early childhood teacher education in Argentina}

The early childhood education and care (ECEC) workforce in Argentina are highly heterogeneous. Practitioners work in a variety of ECEC settings that cater children from 45 days — end of maternal leave — to five years old: official nurseries and kindergartens privately or publicly funded - that sit within the municipal or provincial areas of education; child development centres that depend on the ministry of social development; unregistered private services regulated by the commerce sector of each municipality; and communitybased experiences.

EC teacher education is offered by non-university institutions. The degree has a fouryear duration, after which teachers receive a certification. Although this certification is only required to work as a teacher in official nurseries and kindergartens, it is widely recognised and spread over the country as a symbol of teacher professionalism.

Argentina was the first Latin American country to institutionalise early childhood teacher education. The first ECE teacher education programme started to be offered in the decade of 1870, and consisted in a set of ECE courses oriented to primary school teachers in the Escuela Normal de Paranál.

However, there were doubts around the benefits of extra-familiar educational institutions for very young children, which led to the courses being shut down several times

\footnotetext{
${ }^{1}$ The escuelas normales were secondary level institutions where training for primary school teachers was offered.
} 
until the 1930s (Simon, Ponce, and Encabo 2017). The lack of recognition of the importance of education and care institutions for very young children left an indelible mark in the EC profession. The demands over professional recognition have been present in the ECE professional community since its foundational period.

In 1938, the first teacher education institute (Instituto Nacional de Profesorado Sara Chamberlain de Eccleston) was founded, influenced by the ideas of Froebel, Decroly and Montessori. It only admitted women who held a diploma from escuelas normales. Strictly speaking, this meant that the early childhood degree was a specialisation for certified primary school teachers.

However, it was not until 1969 that the preparation of early childhood teachers became an independent two-year degree to work with children from three to five. The achievement of this demanded 'independence' from primary school teacher education intensified long standing debates around the meaning of ECE, and its differences with the contents and methods of primary school.

Two subsequent reforms in the 1990s and 2000s extended the degrees to three and then four years. The last reform expanded early childhood teacher education to include nurseries — named maternal gardens in Argentina - for children from 45 days to two years old, both in the curriculum and in the placement experiences (Fernández Pais 2018). The inclusion of the earliest years within the scope of ECE has brought about debates around the educational meaning of working with very young children (e.g. changing dippers).

\section{Methods}

In this paper, I draw on a single case study of a Teacher Education Institution (TEI) in Buenos Aires. The project aimed at studying how teacher educators pass on their practical wisdom in situ (Guevara, 2019). My aim was not to achieve generalisation, but rather to 
study the specific (Stake 1995). As Flyvbjerg (2006) argues: 'formal generalisation is overvalued as a source of scientific development, whereas "the force of example" is underestimated' (p. 221).

The case was chosen based on two criteria: sensitivity and convenience. On the one hand, the TEI was a sensitive case due to the high prestige and track record of the selected institution, among those offering the reference degree. Hence, this was not only important in instrumental terms - meaning the study of a concrete unit of analysis at the service of studying a specific phenomenon-, but also in intrinsic terms — the knowledge of a concrete unit of analysis finds its value in itself- (Stake 1995).

On the other hand, the case was selected due to the feasibility of access to the field. I was acquainted with an educator that worked in the TEI and acted as gatekeeper, introducing me to the teacher educator. After the first introduction, the research project obtained the approval of the TEI ethics committee. We agreed there anonymity would be guaranteed both for the TEI and each of the research participants.

My fieldwork followed an ethnographical approach, considering it both an approach and a method (Guber 2001). Data were collected over two years of fruitful immersion in the daily work of teacher educators and student teachers. Starting as an outsider, I progressively built a relationship with teacher educators and student teachers. During this time, I conducted eleven in-depth interviews with teacher educators (placement tutors) and 153 hours of participant observation in placement workshops. Placement workshops are the curricular instances around which field experiences are organised in teacher education in Buenos Aires. During field experiences, student teachers attend the TEI once a week, and they spend the other four days of the week at the placement school. The workshop at the TEI is focused on preparing for, guiding student teachers through, and reflecting on the placement experience. Teacher educators organise the workshop in the TEI and are present once a week at the 
placement school. Placement schools were both nurseries (45 days to two years old) and kindergartens (three to five). I participated in the workshops at the TEI and followed teacher educators to placement schools, where they went to supervise student teachers.

I approached the analysis of interview transcripts and field notes from a grounded theory perspective. I analysed the data with the help of Atlas.ti software. I started data analysis during the fieldwork, and the first insights were used to conduct the following observations and interviews. During that phase, I focused on grounded concepts through open coding, and I ended up with 189 codes. Subsequently, I moved towards axial coding to identify relationships among open codes, which reduced the categories to 27 . Finally, I reread the full dataset and, through selective coding, I constructed eight core variables and their relationships.

\section{Results}

I found that professionalism was defined and negotiated around its borderlines. Moreover, its borders seem to be an inextricable part of what it means to act as a professional in ECE. In this case study, professionalism could be interpreted as a territory resisting an invasion. In the placement as an arena of struggle, teacher educators would resist banalisation, schoolification and fordification.

The following paragraphs present banalisation, schoolification and fordification as enemies of professionalism in ECE. Each of them entail profound ethical and political discussions. However, as I will suggest, the battle is fought in a depoliticised way.

\section{Banalisation: don't act as a maestra jardinera}

On multiple occasions, teacher educators acted in reaction to what they called the stereotype of the maestra jardinera, which literally translates to English as garden teacher. Unlike 
profesora de educación inicial (early education professor), maestra jardinera has a negative connotation within the professional community because, on the one hand, a professor is more prestigious than a teacher, and on the other hand, it wipes out the main focus of EC educators: early childhood.

The underlying presumption is that ECE is a simple task that requires little professional preparation and relies on mimicking children's processes instead. This banalises ECE to the point of making invisible — and even denying — its educational character. As Gloria tells her student teachers, who are about to start their placements:

[When sending our introduction letter] we need to consider who the recipient of the note is: the parent (and not the child), the parent who is an adult, so using a 3D dachshund dog card is not necessary. We should not address them as 'dear mummies and daddies' because they are adults and not necessarily mother and father; instead, we use 'dear families'. Then, we introduce ourselves. Even if we don't like presenting ourselves as maestras jardineras, to some families the term 'early education professor' means nothing. We have to adapt to the population, and that's why we change it, but, actually, you are studying to become early education professors. What I do not want, and nobody here wants, is anything childish because we are adults addressing adults (Observation transcript, April 2015).

Gloria clearly states the terms maestra jardinera could only be used for student teachers to introduce themselves to the families. She makes it clear that the communication is between adults and wants student teachers to avoid childish approaches.

On other occasions, banalisation is interpreted as being part of the 'culture of kindergartens', materialised in the practices of cooperating teachers. The perception that the 'kindergarten culture' trivialises and de-professionalises the role of the EC educator appeared repeatedly in teacher educators' discourses. In the post-placement feedback of a student who 
had taught the broomstick game ${ }^{2}$ in a four-year old's classroom, Marisa identified some problems:

You got entangled and made the explanation quite confusing. All those questions were not necessary. It was as if you couldn't help mimicking kindergarten teachers' habits... this thing about wanting the kids to tell you everything. But the point is that by asking things to the kids, you are not being more child-centred, that's not the best approach. If they don't know the game, you're the one who is going to teach them how it is. In such a situation, you have to play your adult role as a mediator between the child and a cultural heritage. Questions make sense when I can actually take something from those questions but, in this case, their answers were useless to you and, in addition, you asked them questions as if you were seeking a magical answer, and it practically turned into divination (Observation transcript, June 2015).

In this excerpt, banalisation is associated with a superficial understanding of childcentred pedagogy. From Gloria's perspective, with the intention of putting children as the centre and starting point, the educational experience is trivialised. She refers to a difference between a pedagogy that is respectful of the child and superficial participation that entails a childish way of approaching ECE. Mónica holds a similar view, which she expresses during post-placement feedback she gave to student teachers:

I wanted to highlight something I heard in your classroom. The cooperating teacher said, 'my friends, the letters' and (...) you, the other day, said 'my friends, the numbers'. It is nothing against this teacher; it is very easy to blend ourselves in with this culture of kindergartens where everything is trivialised, and diminutives are used. It is deprofessionalising. I mean, besides banalising friendship, and letters, and numbers, it contributes to this stereotyped view of the kindergarten teacher who uses diminutives for every word (Observation transcript, April 2014).

\footnotetext{
${ }^{2}$ It is a popular dance game in Argentina.
} 
In this fragment, banalisation is explicitly mentioned and linked to deprofessionalisation. According to Mónica, if the student-teacher acts in a childish manner, she banalises the profession.

\section{Schoolification: don't act as a primary school teacher}

For teacher educators, schoolification threatens ECE professionalism and is embodied in the figure of the primary school teacher. Schoolification has usually been referred to as 'primarisation' (primarización) in Latin America. In fact, teacher educators tend to contrast ECE and primary education. The latter is considered as an institution in which the child and, consequently, play - disappears from the centre of the scene and contents are not significant for the children. The enemy of schoolification is embodied in the image of the primary school teacher.

Teacher educators argue that schoolified practices are present in many kindergartens. Thus, they clearly see a risk in student teachers acting as (and becoming) primary school teachers. As Ana Laura develops:

...if we are planning language activities, children need some support, but not the traditional alphabet task you see at primary schools where they have to put the [letter] "P" next to [the word] "Plane". (...) In early education this area is usually overlooked because of [teachers'] lack of awareness; and when it is approached, it is done primarising, resorting to the worst practices of primary school in kindergarten (Observation transcript, June 2015).

In the excerpt above, the schoolification of kindergarten is associated with educational practices that are not meaningful to the child. It can also be linked to the "professional appropriateness' of certain contents, as Mercedes states:

...sometimes problems arise, for instance when cooperating teachers request things that are professionally inappropriate. (...) One of them has asked the student teacher to plan a 
sequence of activities on Maths in a toddlers' classroom. And in nursery we don't work with Maths... I could go and say 'look, you are in the oven ${ }^{3}$, you haven't understood a thing, this is nursery'. But there is another option, to ask ourselves what could be done with that request. We could build a proposal we actually find interesting. For instance, once we organised a relay game where children jumped at the count of 'one, two, three...'. (...) I don't really care, anyway 'one, two, three...' is a recitation that exists for the child. What I don't let [student teachers] do is a cardboard that says 'blue and red = violet' (sometimes even with the plus sign). That would be a totally insurmountable crap, you get me, right? If that is the case, we do talk to the cooperating teacher and explain why that is inappropriate (Interview transcript, June 2014).

Mercedes argues against the schoolification of nursery. Schoolification appears here as a phenomenon materialised in certain approaches, such as teaching maths to a toddler's group, present in ECE settings. However, from Lara's perspective, there are risks attached to resisting schoolification too hard.

...I really consider ECE level as pioneer, the most creative level, it is a pride to belong to this level, etc. We also have discussions, I know primary school is rigid and superficial and all that (...), but the truth is that the role of the school is to educate: educate well, educate respectfully, educate significantly; but educate, because otherwise, what is its raison d'être? (Interview transcript, placement teacher, April 2014).

Lara suggests that sometimes by trying not to mimic primary school's worst practices, the educational — in its broadest sense — role of kindergarten is forgotten. An ECE professional should avoid primary schools' contents and practices, but without losing the meaning of the educational enterprise.

\section{Fordification: don't act as a factory worker}

A third enemy of professionalism in ECE for teacher educators is what I call fordification, in reference to Henry Ford's factory model. Teacher educators were fiercely critical of practices

\footnotetext{
${ }^{3}$ Local expression meaning you are in a compromised and critical situation.
} 
that mimicked mass production, where the educational value of daily activities was lost.

The iconic image of fordification, which teacher educators mentioned repeatedly, was to 'change nappies like in the factory' (Interview transcript, teacher educator, March 2015). Alejandra explains this to student teachers about to go to placement:

If we arrive and [the cooperating teacher] changes the nappies as a quick procedure, we will not do it like that (...) When I studied, they would tell us that, while changing nappies, we should teach textures. That is to think that changing nappies is a waste of time and that I have to use that time to [teach] something else. But actually, we should think about what is important for the child in that moment [when nappies are being changed] (Observation of workshop, March 2015).

As shown in this passage, the problem arises when daily activities are transformed into a 'quick procedure' that loses meaning. One of the main characteristics of the Fordist model is the standardisation of products: everything is produced through machines and moulds by unskilled workers. In that model, the hand, the head and the heart are disconnected and therefore meaning is lost.

From teacher educators' point of view, fordification is also present when the kindergarten classroom is transformed into a series of meaningless rituals. In the following extract, Luisa talks to student teachers about their placement experiences:

...the idea is that circle time should not become a routine, we don't have to always do the same thing every day. Children shall find the purpose of that circle time. Why do we have to always count how many children there are? If we want to count, for example, we might count in order to tell the lady who brings the biscuits how many she has to leave (...) It has to have a purpose because, otherwise, it becomes mechanical, like a routine, but does not make educational sense (...) These circle time exchanges shall not be routines or rituals. They are interesting spaces (...), but as long as they are not something mechanical (Observation transcript, May 2014). 
From Luisa's perspective, even the most meaningful activity might lose substance if repeated mechanically every day. Thus, fordification is not only present in nurseries but also kindergartens. Educational meaning seems to be the key to act professionally in ECE from teacher educators' perspectives.

What is more, fordification also has a disciplinary effect:

An EC educator must have a set of valuable resources (...) But, 'resources' is a bit of a dirty word here. Almost elements of torture, I would say... Those kinds of things used to achieve discipline or to mechanise certain functions: each thing has its own song and the relationship between what is done and the song loses meaning. For example: 'hands below the bottom', 'a hair clip in the mouth', 'glue in the bottom'4. We have fought so much against these things in the past (...) A good proposal is worth more than a thousand "come here and sit down" (Observation transcript, March 2015).

In the excerpt above, Gloria refers to a set of traditional ECE phrases used by EC educators to indicate that the group should remain seated and quiet. For teacher educators, this way of summoning children is disciplinary ${ }^{5}$.

Factory workers were meant to be disciplined. Corporal and behavioural discipline could be considered as part of an industrial approach. Teacher educators find disciplining messages hidden under many apparently innocent songs and phrases used mechanically in ECE settings.

\section{Discussion}

What does it mean to act professionally as an early childhood (EC) educator? The answer to

\footnotetext{
${ }^{4}$ In Spanish, manos en la cola, broche en la boca, and pasticola en la cola either rhyme or have a certain musicality to them.

${ }^{5}$ In fact, there is a famous text in ECE in Argentina (Kantor 1988) that relates the use of this phrases to the last military dictatorship (1976-1983). The author argues that getting rid of those manners is an essential part of democratising ECE.
} 
our initial question is not (and could never be) universal - it is always preliminary, embedded in the local context, and constantly redefined in interactions. In fact, professionalism has been widely discussed as a historically, culturally and socially situated phenomenon. From that perspective, it cannot be accounted for without the voice of the professional community. This article aimed at enabling those voices.

analysed ECE teacher educators' perspectives on what it means to act professionally in the ECE field in one TEI institution in Buenos Aires (Argentina). Professionalism was analysed as emerging from the interaction between members of a professional community in practicum placements, one of the immediate contexts where ECE professionals act and interact.

The results show are practicum placements are arenas of struggle where professionalism is (re)negotiated through practices of assertion and resistance. These practices of assertion and resistance act as bordering practices, in the sense that they draw borderlines between what it means to act professional and what does not. ECE teacher educators resist banalisation, schoolification and fordification, which they perceive as 'deprofessionalising' and 'enemies' of the profession. By doing so, they assert education as a significant, respectful and intentional practice.

The results also show the positions asserted and resisted by ECE teacher educators are based in and inextricably linked to their practical wisdom. Practical wisdom seems to be built no only on individual experience, but also on collective experience.

Regarding the individual experience, ECE teacher educators refer to banalisation, schoolification and fordification in relation to their own experience. It is thanks to the awareness and sensitivity that built over the years that they select, recreate and highlight certain aspects of professional practices over others. 
Regarding their collective experience, their discussions around professionalism relate to critical issues from the past and present of ECE. As mentioned above, the lack of recognition, the relationship with primary school, and the educational meaning of working with babies and toddlers have been present in the ECE field debates in Argentina. These debates can be easily linked to the discussions around banalisation, schoolification and fordification.

Thus, while part of the literature has discussed professionalism in ECE in technical terms, these results suggest professionalism unfolds from collective and individual practical wisdom. It is not about skills and qualifications of the individual practitioner, but rather about relationships between actors of the professional community and their institutional environment (Dalli, Miller, and Urban 2012).

Finally, a final caveat remains to be developed. In these practices and discourses of assertion and resistance around professionalism, professionalism seems to be depoliticised. Research participants always referred to banalisation, schoolification or fordification through imperatives - 'what I do not want, and nobody here wants', 'what I don't let student teachers do', 'we will not do it like this' - These practices and discourses seem to transform resistance (a political practice) into professorial imperatives (a technocratic practice).

Following Moss (2007), antagonism is intrinsic to human relations, but that can take different forms. The predominant form in this study tries to eradicate the source of unrest, as opposed to the recognition of the existence of a field of struggle where competitive visions are sustained. Antagonisms build enemies that must be banished. On the contrary, agonism recognises adversaries whose ideas are to be defeated, but whose right to defend them is not called into question. When the other is recognised as an adversary, recognition of his position is charitable, in order to enable discussion. Moreover, such dialogue implies the possibility of transforming positions and intentionally giving up control over results. 
When the other is recognised as an adversary, then there is a space for arguments, points of view, and democratic discussion. Thus, a space emerges for a political practice in ECE. A political discussion around professionalism would contribute not to the construction of a monolingual ECE field, but the recognition of its multilingualism.

The author wants to thank Prof. Mathias Urban and Dr. Lorena Fernández Fastuca for their valuable feedback on earlier versions of this manuscript.

\section{References}

Brock, Avril. 2013. "Building a model of early years professionalism from practitioners' perspectives." Journal of early childhood research 11 (1):27-44. doi: $10.1177 / 1476718 \times 12456003$.

Brühlmeier, Arthur. 2010. Head, heart and hand: Education in the spirit of Pestalozzi: Open Book Publishers.

Dalli, Carmen, Linda Miller, and Mathias Urban. 2012. "Early childhood grows up: Towards a critical ecology of the profession." In Early Childhood Grows Up, 3-19. Springer.

Dayan, Yael. 2008. "Towards professionalism in early childhood practicum supervision - a personal journey." European early childhood education research journal 16 (2):15370. doi: 10.1080/13502930802141592.

Fenech, Marianne, Jennifer Sumsion, and Wendy Shepherd. 2010. "Promoting early childhood teacher professionalism in the Australian context: The place of resistance." Contemporary issues in early childhood 11 (1):89-105.

Fernández Pais, Mónica. 2018. Historia y pedagogia de la educación inicial en la Argentina. Buenos Aires: Homo Sapiens.

Flyvbjerg, Bent. 2006. "Five misunderstandings about case-study research." Qualitative inquiry $12(2): 219-45$.

Guber, Rosana. 2001. La etnografía: método, campo y reflexividad. Buenos Aires: Norma.

Guevara, Jennifer. 2016. "La tríada de las prácticas docentes: aportes de investigaciones anglófonas". Espacios en Blanco. Revista de Educación, 26, 243-271. 
Guevara, J. (2019). Transmitir el oficio de enseñar. La formación de docentes para el nivel inicial. Buenos Aires: Teseo.

Kantor, Deborah. 1988. "Jardín de infantes: el autoritarismo que se filtra." La Obra.

Kinos, Jarmo. 2010. "Professionalism - A Breeding Ground for Struggle. The Example of the Finnish Day-care Centre." In Professionalism in Early Childhood Education and Care. International Perspectives, edited by Carmen Dalli and Mathias Urban, 150-5. New York: Routledge.

Lawson, Tony, Melek Çakmak, Müge Gündüz, and Hugh Busher. 2015. "Research on teaching practicum - a systematic review." European Journal of Teacher Education 38 (3):392-407. doi: 10.1080/02619768.2014.994060.

Lazzari, Arianna. 2012. "Reconceptualising professionalism in early childhood education: insights from a study carried out in Bologna." Early Years 32 (3):252-65. doi: 10.1080/09575146.2011.651711.

Lunenberg, Mieke, and Fred Korthagen. 2009. "Experience, theory, and practical wisdom in teaching and teacher education." Teachers and Teaching 15 (2):225-40. doi: $10.1080 / 13540600902875316$.

Moss, Peter. 2007. "Meetings across the paradigmatic divide." Educational Philosophy and Theory 39 (3):229-45.

Peterson, Tiina, Marika Veisson, Eeva Hujala, Ulla Härkönen, Anette Sandberg, Inge Johansson, and Eva Kovacsne Bakosi. 2016. "Professionalism of preschool teachers in Estonia, Finland, Sweden and Hungary." European early childhood education research journal 24 (1):136-56. doi: 10.1080/1350293X.2015.1120529.

Ritter, Jason K. 2007. "Forging a Pedagogy of Teacher Education: The Challenges of Moving from Classroom Teacher to Teacher Educator." Studying Teacher Education 3 (1):522.

Schön, Donald A. 1983. The reflective practitioner: how professionals think in action. New York: Basic Books.

Simon, Noemí Alicia, Rosana Elizabeth Ponce, and Ana Matilde Encabo. 2017. Apuntes de historia y política del nivel inicial. Buenos Aires: EdUNLu.

Stake, Robert E. 1995. The art of case study research. London: Sage.

Trent, John. 2014. "When communities collide: the shared construction and defence of community and identity during a teaching practicum." Teacher Development 18 (1):29-45. doi: 10.1080/13664530.2013.867896. 
Urban, Mathias. 2008. "Dealing with uncertainty: challenges and possibilities for the early childhood profession." European early childhood education research journal 16 (2):135-52. doi: 10.1080/13502930802141584.

_ 2010. "Rethinking Professionalism in Early Childhood: Untested Feasibilities and Critical Ecologies." Contemporary issues in early childhood 11 (1):1-7. doi: 10.2304/ciec.2010.11.1.1.

Zeichner, K. M. (1987). "The ecology of field experience: Toward an understanding of the role of field experiences in teacher development." In: M. Haberman \& J. M. Backus (eds.) Advances in teacher education 3, 94-117. 